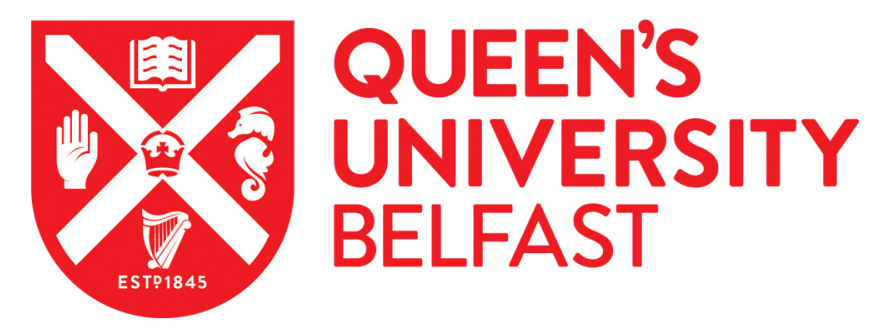

\title{
Making Safe: the dirty history of a bomb disposal robot
}

Lisle, D. (2020). Making Safe: the dirty history of a bomb disposal robot. Security Dialogue, 51(2-3), 174-193. https://doi.org/10.1177/0967010619887849

\author{
Published in: \\ Security Dialogue
}

\section{Document Version:}

Peer reviewed version

Queen's University Belfast - Research Portal:

Link to publication record in Queen's University Belfast Research Portal

\section{Publisher rights}

Copyright 2019 The Authors.

This work is made available online in accordance with the publisher's policies. Please refer to any applicable terms of use of the publisher.

\section{General rights}

Copyright for the publications made accessible via the Queen's University Belfast Research Portal is retained by the author(s) and / or other copyright owners and it is a condition of accessing these publications that users recognise and abide by the legal requirements associated with these rights.

Take down policy

The Research Portal is Queen's institutional repository that provides access to Queen's research output. Every effort has been made to ensure that content in the Research Portal does not infringe any person's rights, or applicable UK laws. If you discover content in the Research Portal that you believe breaches copyright or violates any law, please contact openaccess@qub.ac.uk. 


\section{Making Safe: the dirty history of a bomb disposal robot}

Twenty years after the Good Friday Agreement was signed in Belfast, the Ulster Museum opened its newly designed gallery renamed The Troubles and Beyond. The displays are organized chronologically by decade, and the concluding centrepiece of the exhibition is a raised platform upon which a Wheelbarrow bomb disposal robot is displayed [Insert Fig. 1]. As the accompanying text explains, this machine was invented, developed and deployed in Northern Ireland ( $\mathrm{NI}$ ) at the height of the Troubles, and used by the British Army officers of the 321 Explosive Ordinance Disposal (EOD) Squadron to defuse various types of car bombs and incendiary devices (IEDs) planted by the Irish Republican Army (IRA). The text goes on to explain how many lives the Wheelbarrow robot has saved, and how it is regularly used in conflicts around the world. Placed in such a prominent position in the new gallery, this object helps to tell a more hopeful story about war and its machines. It reassures us that even in the most violent conflicts, there are always efforts to prevent bloodshed, protect civilians and create peace.

While the Wheelbarrow robot anchors a much better narrative than the Museum's previous exhibition on the Troubles (Lisle, 2016: 226-29; Meredith, 2018), I keep circling back to this machine, unable to dispel my feelings of unease at the affective political work it is doing in this space. Since 2015, I have been a member of the Academic Advisory Group (AAG) for the new Troubles and Beyond gallery. I attended several meetings, workshops and events and worked with curators as they developed their collection of Troubles-related objects, designed the exhibition space and managed the overall installation. In all of our AAG meetings, nobody disputed the decision to place the Wheelbarrow robot at the centre of the exhibition. As the head curator of the exhibition explained, careful consideration was given to the robot's position alongside the colour-coded Belfast map showing Protestant (pink), Roman Catholic (brown) and Mixed (yellow) areas, and how together these represented a 'security' response by the British Army (Logan, 2019). She went on to outline 
how this relationship worked through the 3 other object-response pairings displayed on the platform: a metal garbage bin lid used by Nationalist women to warn of British Army presence (a 'community' response); a sculpture of a women being caught up in a bomb blast (an 'artistic' response); and a Spitting Image puppet of UK politician Peter Mandelson who was NI secretary from 1999-2001 (a 'satirical' response) (Logan, 2019). In its central position, the Wheelbarrow robot visually, instinctively and physically orders the surrounding objects on display, creates a hopeful conclusion to the exhibition, and leaves visitors positively disposed to the now peaceful, cosmopolitan city they emerge into. What is not to like about that careful and plural ordering? Who can be against a more hopeful, positive, and reassuring conclusion to a bloody conflict that lasted for decades?

\section{Getting Dirty: how to contaminate a life-saving narrative}

This paper addresses my lingering unease over the Wheelbarrow robot by telling a very different story about its birth and deployment in $\mathrm{NI}$ - a much dirtier history that lies underneath the hopeful narrative offered by the Ulster Museum. I take seriously Bousquet, Grove and Shaw's (2019: 4) encouragement to follow 'the trail of war wherever it leads', and to face, head on, the more uncomfortable complicities that emerge when we refuse to pre-determine war's ontological status. The dirty stories I uncover about the Wheelbarrow robot are not simply 'matter out of place', as anthropologist Mary Douglas (1966/2002) might frame it, nor can they be recuperated into reassuring normative commitments that promise a 'happy ending' to war (Bousquet, Grove \& Shaw, 2019: 10). Rather, these stories are an opportunity to follow Virilio's lead by sticking our hands into the 'bloody guts' of war's stinking cadaver (Bousquet, Grove and Shaw, 2019: 26). I do not dispute the claim that the Wheelbarrow robot was instrumental in saving lives and infrastructure in $\mathrm{NI}$ during the Troubles: it certainly did all of this. But I am arguing that to accept such a benign account, 
or to end the story there, is to efface some of the more problematic practices of war-making that this machine helped to reproduce. In that sense, I want to dirty the clean history of the Wheelbarrow robot by arguing that its life-saving efforts do not absolve it from its participation in, and reproduction of, wider practices of military occupation and violence. Indeed, as Roderick (2010: 236) argues with respect to the latest generation of Wheelbarrow robots deployed in Iraq and Afghanistan:

by valuing the robot as a life-saving technology, the material discourse of the EOD robots contributes to a broader claim that war can be waged while at the same time actually 'saving' lives and, as such, is being used to re-legitimize warfare, a practice that ultimately devalues life.

Indeed, the lethality of such life-saving machines was exemplified in 2016 when, instead of sending in uniformed officers, the Dallas Police Force used a remote-controlled Wheelbarrow robot to blowup sniper Micah Johnson. Over and above the implications for domestic policing in the U.S., this incident forces us to consider the contradictions of 'humanitarian' weapons and the forms of violence that are effaced by seductive stories of machines that protect us (Bradley, 2019: 339; Davis, 2019: 349-350). Using these insights as a starting point, I want to argue that the clean story of the Wheelbarrow robot's invention and deployment in $\mathrm{NI}$ - the account replicated by the Ulster Museum exhibition - enables the British Army to mythologize itself not only as a long-standing incubator of cutting-edge technological innovations, but also as a benevolent peacekeeping force deploying proportionate counter-insurgency methods. My dirty history of the Wheelbarrow robot contests that preferred account by uncovering the many countervailing forces, orderings and practices that this machine produced, and was produced by, as it was trundling through the streets of NI. Following Povinelli (2012; 2014), my intention here is to expose practices of war-making that 
are otherwise, that emerge in tandem with war's dominant narratives but remain opposed to them in usefully disruptive ways.

For me, these otherwise accounts of the Wheelbarrow robot remain invisible if we continue to understand war more generally, and the Troubles more specifically, as resolutely human endeavours. To that end, I draw on the more generative, entangled and materially-oriented approach to war mobilized by this special issue in order to position the robot amongst a much livelier congregation of human and non-human materials, objects and infrastructures than is usually found in accounts of the Troubles (Bousquiet, 2018; Bousquiet, Grove \& Shah, 2019; Grove, 2019; Salter, 2015; 2016; Shah, 2017). The Wheelbarrow robot was not a passive tool that was instrumentally used by the British Army in its efforts to defeat successive IRA bombing campaigns: it was an active agent that powerfully shaped the practices, trajectories and spectacles of bomb disposal in NI. Indeed, the Wheelbarrow robot did not simply obey the instructions of its operators: it was a lively and often stubborn object that spoke back to the humans trying to use, shape, adapt, watch, avoid and destroy it. My point here is that a more generative approach to the multiple human/non-human entanglements of war is necessary in order to foreground the Wheelbarrow robot's agency and understand how, from its birth in 1972, it actively sustained a durable assemblage of conflict in NI.

This paper makes two specific contributions to the generative re-imaginations of war gathered together in this special issue. First, it articulates a cautious approach to agency that has arisen from my own efforts to understand the materials, objects and infrastructures of war through more generative concepts such as assemblage and entanglement (Lisle, 2016, 2018). Too often, we still conceive of agency in human terms; that is, 'we', as humans, graciously afford our agency to the materials, objects and infrastructures around us so that they - like us - can act and affect change in the assemblages they participate in. For me, that account of agency is too uniform: its all-too-human 
legacy lacks texture, depth and heterogeneity, and as a result, we struggle to know how to deal with the brute materiality of the machine's 'thing-ness'. I am not advocating a resuscitation of material essentialism here. Rather, I want to follow Feminist scholars in STS by thinking harder with the machines of war in ways that neither incorporate their radical otherness into our human frameworks and lifespans, nor jettison them to material life-worlds outside of our care and attention (Barad, 2007; Haraway, 2016; Povinelli, 2012; 2014; Suchman, 2007). Thinking otherwise about the Wheelbarrow robot requires that we inhabit, rather than resolve, the struggle between, on the one hand, wanting to assimilate the machines of war by making them more human, and on the other hand, wanting to abandon them as unknowable and radically other in their brutality. Second, I want to honour this effort to 'think-with' machines by articulating a rougher, messier and indeed dirtier account of agency that explores the co-ordinated actions between humans and machines not just in terms of fulfilment, but also in terms of failure, frustration and disappointment. What is not visible in the British Army's preferred account of the Wheelbarrow robot are the variety of ways that this machine, for whatever reason, did something other than successfully save lives, protect property, and defeat terrorism. Indeed, what particularly interests me are the many ways that this machine failed to do what it was supposed to do - when it got stuck, fell over, came apart or blew up. Indeed, the multiple ways in which these failures were negotiated between the EOD operators and the Wheelbarrow robot as it was deployed in the urban landscapes of Belfast and Derry/Londonderry cannot be contained within the British Army's clean history of technological innovation and benign peacekeeping. Telescoping out from the intimate microcosm of testing, adapting and operating, I am also interested in how those human-machine navigations were displayed to, and experienced by, local subjects. How did bomb disposal - and especially the performance of the Wheelbarrow robot itself - become an unruly spectacle that unleashed contradictory manifestations of danger, voyeurism, fear, boredom, violence, curiosity and anticipation? 
To clarify, then, this paper mobilizes a more cautious account of agency to 'dirty' the clean history of the Wheelbarrow robot in five ways. First, while I appreciate how the Wheelbarrow robot embodies the general ethos of the Troubles and Beyond exhibition, I want to deliberately soil the pleasant feelings of hope and redemption that this curated machine offers. I don't do this out of malice or glee; rather, I do this because all cathartic, redemptive and conclusive narratives of war need to be disrupted and opened to further critical scrutiny. Second, much as I acknowledge the life-saving benefits of the Wheelbarrow robot, I do not accept that its ends justify its means; in other words, it is crucial that the more unpalatable aspects of this machine's story - its active participation in the wider practices of war-making and violence - are told alongside its more reassuring mythology. Like the editors of this special issue, I am not interested in erecting yet another normative project that believes we can somehow redeem the good name of war (Bousquiet, Grove \& Shah, 2019). Rather, I'm interested in the experiences and practices of war that fall out of those utopian narratives. Third, I want to contest the British Army's preferred account of the Wheelbarrow robot in order to question its claims of seamless technological innovation and benevolent peacekeeping. I don't do this to demonize the British 321EOD officers involved or to romanticize the IRA bombers. Rather, I do this to argue that any micropolitical genealogy of the Troubles must first acknowledge the asymmetrical colonial circuits that NI was attached to, but then work even harder to foreground how variegated, fragmented and fractured these circuits were. To put it another way, even the clean logic of colonizer / colonized must be made dirty. Fourth, I want to illustrate how this heterotopic landscape does not - and cannot - sustain the British army's preferred account that the Wheelbarrow robot was invented through an intense period of linear innovation in which human expertise ultimately disciplined the machine. What we see instead is a much more dispersed topology of machine agency that is full of the dirty secrets of any technological innovation: failure, frustration and disappointment. And finally, I insist on dirty because it brings us face-to-face with the brutal violence of the Troubles: the fetid intimacy between perpetrators and victims, the shit smeared on the walls by political prisoners, and the dead bodies forever disappeared into bogs and 
slurries. Dirty is an indelible mark that cannot be scrubbed away. Dirty has dark undercurrents that leave a stain: it is foul, squalid and contaminated beyond recovery. The Troubles were dirty and they remain so: they cannot be cleaned up.

\section{A Clean History:}

The accepted story of the Wheelbarrow robot, memorialized in many photographs, news stories, histories, memoirs and documentary films, begins in the early 1970s when the IRA was detonating a huge number of bombs (mostly car bombs), and the British Army's efforts to stop them were constantly lagging behind. In this dangerous rivalry, the British Army - with all the resources, state authority and military technology at its disposal - widely understood themselves to be losing the war (BBC, 2012: 11:11-14; Discovery Channel, 2014: 0:28-0:35). The soldiers at the forefront of this failure were 321EOD squadron; specifically, the human Ammunition Technical Operators (ATOs) who had to get physically close enough to the bomb in order to manually defuse it. By early 1972 the number of ATO deaths had risen dramatically, and it is at this 'low point' in the story that Lt. Col. Peter Miller appears. In March 1972 he attended a meeting at the Ministry of Defence (MoD) with Lt. Col. George Styles, head of Army Bomb Disposal in NI from 1969-1972, to address the crisis faced by 321EOD (Smith, 2006: 173). Following his intuition, Miller purchased a battery powered wheelbarrow from a local garden centre, and over the course of the next 6 months adapted the machine into what became the first iteration of the Wheelbarrow robot that could remotely disrupt, defuse and/or dispose of a bomb before ATOs had to make the dreaded 'long walk' and defuse it manually (Discovery Channel, 2014; Gurney, 1993: 109-110; MacDonald, 1977: 90; Patrick, 1981: 7782; Smith, 2006: 172-76). By October 1972 the Wheelbarrow robot was being used regularly in bomb disposal operations across $\mathrm{NI}$, and Miller and his team kept refining, adapting and improving the machine so that it could deal with the different bombs and IEDs planted by the IRA (Ryder, 2006: 90- 
94; Patrick, 1981: 77-82; Smith, 2006: 172-76). Just a year after Miller had developed the first prototype, the Wheelbarrow robot had gone through 5 iterations and now had a series of interchangeable parts such as a grappling hook, a hammer to break car windows, a claw to grab door handles or release charges, integrated CCTV capability and a clamp. By 1975 the Wheelbarrow had been developed to Mark 7 which lasted through some of the worst parts of the Troubles (Army Information Services, 1992). Although it 'looked like a refugee from a low-budget sci-fi film', ATOs felt that the Wheelbarrow robot was a 'life-saver' and a 'godsend', for example, ATO Steve Smith (2006: 2) claimed it was 'The saviour of the hour, and possibly the saviour of my bacon as well' (Gurney, 1993: 109; McDonald, 1977: 71; Smith, 2006; 78; 166; 177; 214; 228). The robot was widely considered 'a game changer' in the conflict because it significantly reduced ATO deaths, increased 321EODs successes against the IRA's bombs, and consolidated the British Army's counter-insurgency efforts in NI (BBC, 2012: 29:40-30:00).

What holds this story of the Wheelbarrow robot together is the framing of Miller: his ability to remain calm whilst quickly, creatively and efficiently inventing a new machine that would solve the urgent and catastrophic problem of the IRA's car bombs. Indeed, Ryder (2006: 98) explains that 'a great sense of urgency had acted as a catalyst to bend or ignore the rules' which included bypassing all 'normal' forms of bureaucracy to get the Wheelbarrow robot built and deployed quickly (Discovery Channel, 2014: 3:38-42; McDonald, 1977: 70; Plummer, 1976: 11; Ryder, 2006: 98; Smith, 2006: 77-78). Such was Miller's determination in this dramatic atmosphere that it only took him 8 days to build the first prototype (Smith, 2006: 77): 'At this time, the urgency was such that I did not consider following the procedure that protocol demanded and going through orthodox channels when initiating a project. I decided to depend on my initiative, without reference to anyone in authority' (quoted in Smith, 2006: 174). Here, Miller is depicted as a risk-taking maverick who did not play by the rules. He was 'off the wall' and 'unorthodox'; he thought 'outside the box', but his 'quirky mind' ultimately provided 'creative solutions to everyday problems' (Discovery Channel, 
2014: 1:17-1:57). His 'slightly mad engineering wizardry' was tolerated and encouraged because he got the job done; his 'no nonsense' attitude meant he didn't complicate or over-theorize the problem; and his 'economical' approach meant he used what was at hand, no matter how mundane, rather than requesting 'fancy kit'. His diligence, duty and commitment meant that he worked around the clock, including over Easter weekend in 1972, to quickly produce a workable device (Discovery Channel, 2014: 1:17-1:57; Gurney, 1993: 109; Smith, 2006: 174). Because Miller was not overly concerned with 'orthodox channels', he listened to the ATOs using the Wheelbarrow robot in the field, took their critiques seriously, and incorporated their suggestions into each iteration of the machine (Smith, 2006: 176-77). The accounts of Miller as a 'maverick' proliferate because they are anchored by a much more foundational account of a clear-headed, rational and direct problemsolver who was not distracted by the emotional fall-out of continuing ATO deaths, or the overall sense that the British Army were losing the war. Miller thus brings together a number of powerful ideas about British masculinity and genius: like Isaac Newton and James Dyson, he uses unorthodox means to create 'game-changing' technologies, but he also embodies the British cultural bedrock of simply getting on with it.

\section{An Exceptional Colonial Laboratory:}

The central problem with this clean history of the Wheelbarrow robot's birth and deployment is that it effaces the British Army's role in colonial governance and occupation. In the early stages of the Troubles, the practices of British colonial occupation usually deployed 'over there' were suddenly imported into a 'provincial' landscape that was simultaneously part of Britain and not. As Lt. Col. George Styles (1975: 76) explained, 'Those people throwing stones and nail grenades and petrol bombs weren't foreigners. The common complaint from soldier to officer was, 'It's very difficult, sir, because they speak English." As many scholars have noted, the British forces deployed to $\mathrm{NI}$ in the 
early years of the Troubles came directly from other colonial scenes in Aden, Kenya, Cyprus and Hong Kong, and encountered many problems as they tried - and often failed - to import their practices of counterinsurgency so close to home (Benest, 2006; Ellison \& Smyth, 2000: 73-76; Khalili, 2013: 235; Strachan, 2008; Styles, 1975: 76-78). These military circulations through colonial space are especially important in the story of the Wheelbarrow robot because they allow us to see how the British Army produced NI as a space of colonial exception in which the 'normal' rules of war did not apply. As Bigo \& Guittet (2011: 486) explain, 'over several decades, a state of emergency became the normal state of affairs in Northern Ireland', which meant that, like any colonial space, $\mathrm{Nl}^{\prime} \mathrm{s}$ landscape, population and social fabric were made available for a variety of interventions by the British Army and their various military technologies. ${ }^{1}$ In the clean history of the Wheelbarrow robot, what matters is that Miller drove the invention of a new technology to defeat the IRA car bombs, and 321EOD were able to freely test the machine's multiple adaptations across the urban landscapes of NI. What does not matter in this story are the local life-worlds that were used, ignored, exploited, displaced, driven over, occupied or destroyed in order for that machine to be tested, adapted and deployed. For example, we hear about 321EOD's detailed protocol for questioning locals in the vicinity of a car bomb and working with infantry to evacuate people beyond 200m (McDonald (1977: 81-83), but we don't hear from those who were questioned or moved out of their homes, places of work, shops, cafes, parks, gyms, churches and public buildings. My point here is that we cannot see the cost of 321EODs experimentations - the local lives lost, properties damaged and time wasted unless we understand how the British Army's preferred account of the Wheelbarrow robot rests upon a prior understanding of $\mathrm{NI}$ as a colonial exception. Refiguring this story is crucial because it allows us to examine the extent to which the Wheelbarrow robot's deployment across the urban landscapes of $\mathrm{NI}$ amplified, re-ordered or contested the logic of colonial exceptionality.

Unsurprisingly, the British army's institution-wide experiences of colonial occupation were reproduced in 321EODs sense of entitlement to the urban landscapes of $\mathrm{NI}$, as ATO Kevin Ivison 
(2010: 37) admits, 'There was nothing more exhilarating that charging through the city defusing bombs, getting petrol bombed and returning to the PSNI bar to wind down.' It is equally unsurprising that these entitlements were felt by local populations, as one onlooker explained after 321EOD mistakenly blew up a suspect car, 'it almost looked as if they were 'trigger-happy' to get blowing up a car' (Ulster Herald, 1974a: 4). But what distinguished 321EODs sense of entitlement to that of other British army units was their specific understanding of $\mathrm{NI}$ as an always-available laboratory within which they could freely test, improvise and experiment with the Wheelbarrow robot, regardless of the consequences for local life-worlds. While the 'laboratory thesis' has been developed most substantially in relation to Israel's use of Palestinian space to produce 'advanced weapons, security know-how and technology' for export (Machold, 2018: 88; see also Amar, 2013), I find it particularly helpful for understanding how, in the words of one commentator, NI became 'the most fertile laboratory in Western Europe for the product testing of the anti-terrorist industry' (O'Connor, 1978: 10). This specific sense of entitlement is underscored by a familiar spatialization in which the privileged motherland (England) was contrasted with an outlying colonial province (NI) but unlike other British colonial 'outposts' like Kenya and Aden, this province was right next door. Thus, between the first iteration of the Wheelbarrow robot in March 1972 and the following spring, Miller and his team of 'boffins' did the real brain-work of research and development in Southern England (e.g. the Military Vehicles and Engineering Establishment (MVEE) in Chertsey; Vauxhall Barracks in Didcot), while 321EOD tested the machine's systemic improvements and new attachments in live scenarios in the 'wilds' of NI (Patrick, 1982: 82; Smith, 2006: 180). In many ATO memoirs, this spatial hierarchy between the motherland and the province carried familiar colonial echoes, for example, in a letter home to his sister, ATO P.G. Macdonald (1977: 131) explained '...we've got to be nice to the Injuns. Indian country - that's what they call the hairy parts of the province, particularly down near the border, where there's a lot of aggro.' This spatialization required a constant one-way 'flow of suggestions and requests' from EOD321 stationed in NI to Miller's team in England who were able to translate this feedback into new adaptations and 
improvements to the robot (Ryder, 2006: 91-96). As ATO Dave Young explains, 'While we were working on the ground, we were also feeding back information to develop new bits of equipment. We were improvising as we went along' (BBC, 2012: 30:40-53). At key moments, Miller and his team would fly into Belfast to gather additional feedback and witness how these live experiments were working 'in the field', but these forays did not overturn the hierarchical spatialization of knowledge in which privileged forms of research, development and innovation happened in England, while the more dangerous, haphazard and risky forms of testing happened in 'the province'.

\section{Bumpy Transfers of Agency: co-ordination, adaptation and intimacy}

When discussing the work of current EOD robots, Roderick (2010) argues that their material discourses reveal complex transfers of authority and action between human ATOs and machines, and that such feedback loops raise important questions about non-human agency and automation. His point is that a misplaced belief in the robots' autonomous functionality (i.e. that they can defeat the threat of IEDs and protect American solders) encourages a reliance on the ability of technoscience to save lives. What I take Roderick to be saying is that we overestimate the machine's capacity for action by transferring too much agency to it, resulting in an overinvestment in its autonomous capabilities. While his idea of transfer is helpful, I see these interactions as much more bumpy affairs: they are never unidirectional and singular transfers of an identifiable substance called 'agency' (or even authority or action), but rather heterogeneous assemblages full of friction, instability and turbulence where agency appears and disappears in the process of co-ordination. With respect to the Wheelbarrow robot, risk was 'transferred' from the shoulders of the ATOs to the metal mainframe of the machine; in other words, the machine, rather than the ATO officer in his heavy bomb-proof suit, could now perform the dreaded 'long walk' to defuse the car bomb. As ATO Paul Wharton (2009: 42) explains, 'Wheelbarrow can be expected to take many more risks than I.' 
Central to this risk transfer was the management of physical distance and proximity: while the ATOs now remained at a safe distance operating various dials and switches from behind erected barriers, the Wheelbarrow robot had to be close enough to touch the car, and in some cases, the bomb itself. The brute mechanics of this scenario are hard to fathom in our current context of GPS navigation, real-time global surveillance and precision targeting. But in the pre-digital era of the early 1970 s, 'remote control' consisted initially of two long ropes attached to the main body of the robot and manoeuvred by ATO officers, and subsequently an 'umbilical cord' cable that was spooled out as the robot approached the car bomb. This one-way transfer of risk reveals a foundational hierarchy between the valued human inventors and operators (i.e. Miller and his team, the ATOs) and the necessary but ultimately disposable machine (i.e. the Wheelbarrow robot). Lt-Col. Malcolm Mackenzie-Orr, head of bomb disposal from 1972, reinforced this hierarchy on learning that 13 robots had been blown up in action: 'But they could have been people and life is far more important than property' (Keane, 1974: 9). It also made economic sense: the relatively small cost of a Wheelbarrow robot was nothing compared to the average $£ 50,000$ of damage caused by each explosion, or the huge amount of compensation paid to victims and their families (MacDonald, 1977: 75).

The problem with this hierarchy, of course, is that it effectively 'black-boxed' the robot as an inert tool with no active role in the process of invention, testing or deployment. What particularly interests me is how this human/machine hierarchy was overturned by the desires of the inventors and operators to make the Wheelbarrow robot more human and thus position it as central to an emerging pre-digital machine assemblage: ATO-robot-bomb (Bousquet, Grove \& Shah, 2019: 17; 21). This machine was never held at a distance from its human handlers; rather, humans worked in intimate proximity with the machine as they carefully built, manipulated, coaxed, adapted and transformed it to take on more human tasks. At each stage of development, Miller and his team devised machine attachments that would replicate corporeal capacities, for example, a mounted 
camera replicated human eyes; hand-like grips and claws replicated human hands; and tank treads replicated human legs. All of these attachments were intended to make the device do 'human' things like walk, survey, climb, grip, release, smash, lift, dislodge, turn, drop, snip.

These transfers were not enabled by a disavowal of the machine's brute materiality, but by intimate practices of tactile care as ATOs worked with robot attachments. Each mechanical adjustment or adaptation involved the haptic sensations of touching, feeling and fondling (Ryder, 2006: 89-106). Indeed, as de la Bellacasa (2010) reminds us, scientists, inventors and operators never just dehumanize their objects of concern: they attend to, care for, live alongside and love these objects. These practices of care reveal entirely different human/machine relations; for example, the intense year of the Wheelbarrow robot's invention 1972-73 can be understood through a maternal lens as Miller and his team birthed, nurtured and cared for their machine. This is revealed in the language used by ATOs: early prototypes were likened to a pram; the cable was referred to as an umbilical cord; and 'Lofty' Pattinson, who took over from Miller in 1973, was constantly flying into Belfast to 'watch his 'baby' do its stuff' (Patrick, 1981: 77; Smith, 2006: 177). Once the Wheelbarrow robot had been deployed to $\mathrm{NI}$, these relationships became more paternal as the machine became the ATOs' surrogate, loyal help-mate, team-member, buddy and object of affection (Gurney, 1993: 110; Roderick, 2010: 239-42; Wharton, 2009: 42). For me, these intimate practices of care and affection amount to a strange anthropomorphism which contradicts not just the Wheelbarrow robot's subordination to purely human skill, but also its disposability. As the inventors and operators carefully lifted the machine out of its brutish materiality, a whole new set of relations emerged that exceed reductive accounts of agency-filled humans instrumentally using an inert tool. Rather, what we see is a highly contingent redistribution of agency which involved co-dependent feedback loops, recursions and contaminations, and that punctured the assumed superiority - and indeed, masculinity - of the human inventors and operators mythologized in the British Army's preferred account of the Wheelbarrow robot. 


\section{Material Disobedience: the British Army's laboratory of failure}

Within those bumpy and multi-directional transfers of agency, we can see how the Wheelbarrow robot was never quite 'black-boxed', and consistently spoke back to those trying to adapt and use it. In my previous work (Lisle, 2018), I have explored this turbulent human-machine landscape through the difficult experiences of failure that emerge in the process of technological innovation - the disavowed experiences that do not lead to the realization of a successful device. With that in mind, I am not interested in showing how Miller and his team 'failed better' as they worked to produce a successful machine. Rather, I am much more interested in all the hiccups, unexpected hurdles, disasters and bad ideas that occurred in the Wheelbarrow robot's invention and testing phase, but that were written out of the British Army's preferred account of their successful technological innovation against IRA car bombs. For example, ATO memoirs position the Wheelbarrow robot as the triumphant machine whose ingenuity and simplicity beat three other competitors: (i) a wheeled frame that slid under the car and activated airbags so that the car bomb could be towed to safety (abandoned in 1972); (ii) 'The Marauder' with 6 wheels and better tank treads, but with terrible steering and a 'confusing' control box (shelved in 1977 for being too expensive and 'too sophisticated'); and (iii) the 'Foam Pig' which shot tonnes of foam into a car bomb to dampen its blast energy (quickly abandoned for causing massive urban disruption and mess) (Patrick, 1981: 8081; Smith, 2006: 175-184; Wharton, 2009: 47). These failures are important in the British Army's preferred account only to the extent that they are caricatured in a way that sets up the seductive story of Wheelbarrow robot's success. Some of the struggles and frustrations that are silenced by that story can be seen in Fig. 2 depicting ATOs manually preparing, re-engineering, adapting and rejigging the machine before sending (or re-sending) it out to the car bomb.

[Insert Fig. 2 here] 
While the inventors tried to make the Wheelbarrow robot more human, the operators preparing and adapting the machine in the field were deeply frustrated that the machine was not human enough. It was slow, unstable, cumbersome, clunky, and imprecise, and constantly failed to match the visual precision of the human eye, the fine-tuned dexterity of the human hand and the stability of the human gait. For example, ATOs found the CCTV cameras mounted on the machine 'unsatisfactory' because they worked in sunlight but not in low light, and they were often dislodged as the machine trundled over uneven ground (Patrick, 1981: 78). The ATOs also distrusted the depth perception of the images being relayed from the camera and often required multiple people to interpret the images. In cases of uncertainty, an ATO had to be sent out to the robot to provide a more 'accurate' confirmation of its position relative to the car bomb (MacDonald, 1977: 71; Ryder, 2006: 100). In one incident widely televised in November 1972, the Wheelbarrow robot was about to be sent out to disable a car bomb, but the release mechanism on the 'claw' malfunctioned and the robot 'juddered' to a stop, prematurely dropping the Torpex candle which exploded next to ATO Peter Gurney. Still in shock, but frustrated that the robot was 'playing silly buggers', Gurney walked out to the car bomb himself and manually deposited the candle (Gurney, 1993: 112-13; Ryder, 2006: 94-95). One of the biggest frustrations was the Wheelbarrow robot's notorious instability on uneven surfaces: because it kept falling over on its way up to the car bomb, ATOs had to remotely manoeuvre the machine very slowly and very carefully, often recalling it to make adjustments. As one 321EOD staff sergeant remarked, 'This machine was very unsophisticated... it would often fall over if it came into contact with the edge of the pavement' (Smith, 2006: 176). In one incident involving bombs planted on a railway line, ATOs became so annoyed by the robot's instability that they strapped it to a wagon and sent it out to the bomb (Our Northern Staff, 1974a: 1, 8). 
Much of the ATOs' frustration was focused on how long the Wheelbarrow took to perform tasks that they - as humans - found both easy and quick (e.g. seeing; holding; walking). In one particularly revealing story, 'Robot Willie' took over 2 hours to travel 100 yards from the protected ATOs to the car bomb: it kept dropping its charge and had to be repeatedly returned and re-set. At one point, a neighbourhood cat tried to attack the dropped charge, and eventually the robot's arm became stuck inside the car (Farrelly, 1976: 4). In many cases, the charge deposited by the robot failed to detonate, which meant the whole procedure had to be repeated, sometimes more than once (Our Northern Staff, 1974b, 1; Irish Independent, 1973a, 24). In one particularly gruesome episode, four successive Wheelbarrow robots were unable to get over a hill to retrieve a booby-trapped body. When the final robot managed to insert a hook into the clothing and begin the journey back, the corpse's trousers came down and then its head fell off (Smith, 2006: 116-17; see also Wharton, 2009: 44). Other repeated machine failures included being unable to open the car door; batteries failing at the worst moment; the cable getting tangled in the robot's tracks or chopped by the car's wheels; and when the radio controls of Mark 6-7 went down, it often 'became a rogue' machine independently crashing into walls and buildings (Gurney, 1993: 110; Patrick, 1981: 78-79; Smith; 2006: 180; 182; 222-23; Wharton, 2009: 42; 59). Certainly, these failures were intensified by the atmosphere of urgency surrounding each bomb disposal, but they were also amplified by the ATOs' constant awareness of the consequences of machine failure. If they could not manipulate the various camera, grip and track controls to make the robot defuse the car bomb remotely, the ATOs would have to emerge from behind their barrier, don the heavy bomb-proof suit, and make the 'long walk' up to the car bomb themselves. As ATO Steve Smith (2006: 2; 5-6) explained, 'The last thing I wanted to do was get the big green suit on and go wandering down to look into the mouth of the dragon when it could still wake up and breathe fire all over me.' This always-present fear increased the ATOs' frustrations: they wanted the machine to do something, but the machine refused to do it, or did it incorrectly. For me, this is where the machine spoke back most clearly to its human operators, frustrating their efforts to make it behave like a human, and disrupting any smooth 
account of innovation that sequentially incorporates each failure into an ultimately successful machine.

Outside of the microcosm of operator-robot co-ordination, ATOs were also haunted by a fear that the IRA were winning the war because they were so good at making, planting and detonating bombs (Keane, 1974; MacDonald, 1977: 133-35; Stanhope, 1973). Within the British Army's preferred account, the IRA's success from 1968-1971 was the very raison d'etre for the Wheelbarrow robot programme in the first place, and the main problem that the robot is, retrospectively, said to have solved. This intense rivalry between the IRA and 321EOD was often referred to as a 'cat and mouse' game in which each new IED innovation was met with an equal innovation in detection and disposal. As ATO P.G. Macdonald (1977: 138) explains:

In no previous bombing campaigns had there been such a clear-cut scientific stroke and counter-stroke, but this was a new dimension in this type of warfare. The battle between the Irish bombers and the army's experts became one of ingenuity and improvisation countered by applied science and adaptation.

Reflecting on their experiences in NI during the early 1970s, members of 321EOD squadron now acknowledge the mechanical and engineering sophistication of the IRA bombers, admitting that the IRA were 'highly professional', 'very intelligent people' who had a 'gung-ho' attitude to work, and whose self-taught electrical engineering skills were 'absolutely outstanding' (BBC, 2012: 45:29-46:19; Ryder, 2006: 80; Wharton, 2009: 35). While this gentlemanly (if begrudging) respect for one's enemy is very familiar in British military history, it singularizes what was a much more confusing mixture of fear, admiration, dread and anxiety, but also surprise that the IRA were so good at making bombs. As the Wheelbarrow robot was being invented and deployed, the IRA were performing similar actions of inventing, experimenting and testing, only they were succeeding in clandestine laboratories, using 
illegal global supply chains, and performing experiments while trying to avoid surveillance and infiltration. As Gill's work (2017) shows, the Provisional IRA demonstrated unparalleled amounts of innovation and expertise with respect to IEDs. In particular, the Antrim Brigade conducted complex and wide-ranging experiments in the countryside, while the largely independent South Armagh Brigade were instrumental in developing radio-controlled bombs (Gill, 2017: 581-83). My point here is not to romanticize the innovations carried out by the IRA, but rather to insert its strangely parallel life-world into the story of the Wheelbarrow robot. Miller and his team, as well as the ATOs trying (and often failing) to get the Wheelbarrow robot to work, were haunted by these always-presentbut-seldom-visible doppelgängers who were also engaged in technological innovation - only with self-taught engineers, rudimentary household materials, and makeshift laboratories.

\section{Hearts and Minds: the spectacle of bomb disposal}

The intimate circulations of agency and action between the Wheelbarrow robot and its human inventors and operators were not isolated from the wider surroundings of the Troubles; indeed, each microcosm of bomb disposal was also piece of theatre with a ready-made audience. Initially, 321EOD went to inordinate lengths to hide the actions of the Wheelbarrow robot, fearful that the IRA might gain a tactical advantage from observing how it worked. As ATO Dave Greenaway explains, 'There was always a terrorist watching us, watching what we were doing' (BBC, 2012: 27:20-27:30). However, as the British Army realized their presence in NI was moving from a short episode of policing to a long period of counter-insurgency, they quickly enrolled the Wheelbarrow robot in a wider 'hearts and minds' campaign (Dixon, 2009; Kennedy-Pipe \& McInnes, 1997). Newspapers like the Ulster Herald ran extensive photo essays on the Wheelbarrow robot, and Lt-Col. Mackenzie-Orr, a 'no-nonsense individual' in the mould of Miller, was adamant that the machine caused 'no end of interest to the Belfast public' (Keane, 1973: 9; Ulster Herald, 1974b: 4). For example, in a 1973 letter 
thanking Miller for inventing the robot, he explained: 'Wheelbarrow is almost as popular with the press and local populace as it is with the ATOs... Its appearance is always greeted with a popping of flash bulbs, whirl of cameras and applause from the bomb scene spectators' (Ryder, 2006: 99). Central to this narrative was a portrayal of the local population as grateful for the heroism of the ATO and his faithful machine, and happy to see it on their streets. For example, when McKenzie-Orr recounted the robot's disposal of a 700lb bomb in Belfast, he explained: 'Afterwards people came to me from the Markets area (a Republican district) and simply said they were glad I was all right. I found that 99 per cent of people were friendly' (Keane, 1973: 9). On some occasions, the gratitude of local populations transformed into a 'party atmosphere', for example, as ATO Dave Greenaway cleared an IED device from a department store, the crowd began singing the Football chant 'Nice One Cyril!' (BBC, 2012: 21:45-22:10). Alongside these public spectacles, the Wheelbarrow robot was demonstrated for UK Prime Minister Callaghan during his visit to Belfast in 1977, and an early version was displayed within the Ministry of Defence in England (Stanhope, 1976: 2; Walker, 1977: 1).

Within this 'hearts and minds' campaign, the Wheelbarrow robot was not only the protagonist in bomb disposal spectacles watched by 'grateful' locals, it was also central to the British Army's understanding of itself as a benevolent peacekeeper that remained above the fray. As Lt. Col. George Styles (1975: 78) explained: 'Our job was to try to restore order. Our problem was that there appeared to be no sides, just a whole mess of fish in a tank fighting each other.' This suggests that through all their life-saving efforts with the Wheelbarrow robot, the ATOs never engaged in violence; as ATO Peter Gurney explains (1993: 117) 'I'd thought these people might understand the simple facts of life. That we weren't the ones who were destroying their city. Blowing up their places of employment. Denying them a future.' This narrative of the British Army as a 'neutral bystander' is, of course, unsustainable. Evidence of collusion between British forces and Loyalist paramilitaries shows they were very far from neutral with respect to sectarian divisions; but more importantly, 
these partialities were inherited from scenes of previous colonial occupation (McGovern, 2015). What interests me here is how $321 E O D$ reproduced these asymmetries when framing the local populations who watched them work. They did not see the 'fish in a tank fighting each other' as an amorphous whole; rather, there were (a) 'people who are conscious of their responsibilities as citizens' (i.e. those who cooperated with 321EOD and expressed gratitude for the Wheelbarrow robot); (b) the 'divided, anarchic communities' who did not show appropriate gratitude or cooperation; and (c) the 'bloody-minded elements of the population' who were driving the conflict (Macdonald, 1977: 83-84). For ATO Kevin Callaghan (1993: 79), a particularly violent car bomb 'brought it home to me with a sickening feeling just what sort of barbarians we were dealing with.'

This taxonomy of 'good' and 'bad' locals allowed 321EOD to distance themselves from everyone during bomb disposal and disregard the value of everyday life-worlds that were suddenly, and often mistakenly, caught up in these episodes. Because the car had become 'an object of fear and suspicion', parking in the city centre of Belfast was rigidly controlled, highly monitored and subject to sudden change (MacDonald, 1977: 138). In many cases, if you did not pay attention to car parking restrictions you returned to find the area around your car evacuated and the Wheelbarrow robot in action, or if you were too late, your car had already been blown up (Irish Independent, 1973b: 24). For example, in the Spring of 1974, Ruby Thompson parked her Austin Maxi on John St. in Belfast and went into the hairdressers. 321EOD were informed there was a 'suspect car' in the area: they sealed off the streets, evacuated the houses and businesses, cordoned off the crowds of sightseers, and sent the Wheelbarrow robot out to place a charge inside the car. Thompson became aware of the commotion just minutes before the explosion, and had to watch from the door of the salon as her car was blown up (Ulster Herald, 1974a: 4). Niall (personal interview, 2019) recounted a different experience when he and his friends drove out to Bangor one sunny day for a walk along the seafront. Nervous that he had not updated his car tax, Niall parked his car 100 yards before the RUC checkpoint. After walking along the sea front and getting ice-cream, Niall and his friends returned to 
find the area on full alert, completely evacuated and the Wheelbarrow robot trundling out to his untaxed car. Niall was frisked against the wall ('it was not friendly') but was able to explain himself to the Army officers before the Wheelbarrow robot dropped its charge.

\section{Excessive Spectacles: anticipation and voyeurism}

A much more common experience for local populations was being evacuated when 321EOD and the Wheelbarrow robot were called to a bomb scene (Our Northern Staff, 1974b). For the British Army, these were the grateful, patient and appreciative crowds who watched the Wheelbarrow robot at work. In this narrative, the spectacle of bomb disposal is assumed to be short, exciting and ultimately successful; however, as we know from the many failures of the Wheelbarrow robot, these events often took hours and sometimes days, with many delayed, repeated and aborted attempts. In these scenarios, it is unsurprising that initial curiosity about the Wheelbarrow robot soon dissipated into irritation and resentment as 321EOD occupied the space needed to adapt and troubleshoot the machine. My point here is that flattened assumptions of gratitude do not explain the multiple (and often uncomfortable) responses generated by the crowds who watched the Wheelbarrow robot at work - crowds that were always much more (and much less) than simply 'grateful' as they gathered in front of a live scenario with the very real possibility of violence. As Fig. 3 , shows, there would have been curiosity at scenes of bomb disposal as spectators tried to see past the British Army officers cordoning them off, but there would also have been boredom, irritation, distraction, weariness, conviviality, resignation and anger [Insert Fig. 3 here]. Indeed, on the many occasions when the Wheelbarrow robot fell over or failed to do its job, it drew 'jeers of derision from hostile onlookers' (Ryder, 2006: 95). ATO Peter Gurney (1993: 117-18) recalls being 'taunted and screamed at by Catholics', and in one episode where he was disposing a nail bomb, 'A chunk of rock whistled past me and people yelled, applauded, screamed abuse; it was like trying to work in 
the presence of a manic Greek Chorus' (Gurney, 1993: 118-19). Gurney was unable to complete the bomb disposal because someone in the crowd threw a bottle filled with battery acid which burned through his heavy bomb disposal suit and flak jacket.

What interests me in this melee are the complex feelings of voyeurism, anticipation and excitement that the arrival of the Wheelbarrow robot produced. Although most Wheelbarrow robot spectacles ended up being long and boring episodes of trial and error, they derived their affective charge from a dramatic anticipatory structure. Either the Wheelbarrow robot would succeed in placing a charge in the car which would result in a big explosion (i.e. a reasonable pay off); or, the Wheelbarrow robot would fail to defuse the bomb, which would necessitate the 'long walk' of the ATO who could be blown up right in front of their eyes (i.e. the most shocking pay off). In effect, the Wheelbarrow robot was the most dramatic form of live theatre available. That affective structure of anticipation was clearest when the Wheelbarrow robot first appeared on the bomb scene and audiences gathered to watch it. ATO P.G. Macdonald (1977: 81) recalls an episode of bomb disposal in the Creggan area of Derry/Londonderry which was 'observed by dozens of Irish heads craning round window and door frames and watching the robot go into action.' As a child growing up in the Creggan area in the early 1970s, Claire lived very close to the British Army barracks and remembers wanting to get as close as possible to the Wheelbarrow robot:

I have very clear memories of the robot. You just went along as a child, you watched and observed. I can remember seeing them regularly. We would've stood around quite close to the robot. The soldiers kept you at a distance, but we could still watch them...I found it entertaining, it was something to look at. We watched it do its work, and we watched the soldiers (personal interview, 2019).

Claire had a clear sense that the Wheelbarrow robot wasn't a threat (indeed, she found the helicopters much scarier), but 'there was fear underpinning everything, you knew there was 
something wrong when the robot appeared. Some people laughed and joked, but you didn't know which way it was going to go, a positive or negative outcome' (personal interview, 2019).

That strange combination of curiosity, voyeurism, fear and danger is echoed by Niall who grew up near the Irish border, and remembers being both scared and excited when he and his mom went into Newry one day and were turned away because the Wheelbarrow robot was defusing a bomb. As a boy of 6, he was desperate to 'hear the really big bang' of the car bomb explosion, and consequently upset when the British Army prevented them from seeing the robot in action. Later, as a teenager, Niall remembers a more fraught interaction as he and his friends were returning from school in Newry and saw the Wheelbarrow robot being deployed. They were curious and wanted to get a better look at the machine, but the Squaddies (possibly Royal Marines) were rough as they pushed Niall and his friends back. As a young adult wearing a uniform from a local Catholic school, he remembers this as a pivotal moment in learning how to engage with members of the British Armed Forces (i.e. never get separated from your group; never become isolated behind a soldier) (personal interview, 2019). What strikes me most about Claire and Niall's encounters with the Wheelbarrow robot is the depth, multiplicity and diversity of their feelings, none of which can be contained in deferential accounts of 'gratitude'. Their textured accounts of curiosity and anticipation are mirrored in the faces of those in Fig. 3 caught peering around the British soldier, jostling for a better view, or returning the camera's gaze. These multiplicities are important because they puncture the British Army's preferred account that the locals were simply grateful for their benign peacekeeping actions; in fact, local populations never piously obeyed this narrative, nor could the plurality of their behaviours be reduced to either friendly or hostile. They were, like any crowd, a riotous melee of dispositions and desires.

\section{Wheelbarrow Robots Around the World:}


The British Army's preferred account of the Wheelbarrow robot as a strategic 'game changer' in counter-insurgency has been further consolidated as the technical specifications, operating procedures and ethical protocols developed in NI are now considered the Gold Standard for defusing bombs and IEDs worldwide:

[321EOD's] innovative techniques provided the origins for the modern international template for successful bomb disposal. Thus, more sophisticated versions of the Wheelbarrow robot, pioneered by trial and error on the streets of Belfast, have now become the standard remote-control tool internationally for defusing bombs safely from a distance, minimising the risk to individual officers (Ryder, 2017). ${ }^{2}$

As Garrett Collett, the British Army's current director of EOD, explains, 'the hard yards earned by those guys in Northern Ireland in the early 70s have formed all the philosophy and principles that we have for improvised explosive device disposal' (BBC, 2012: 00:56-1:20). EOD robots have been especially important disarming IEDs in Iraq and Afghanistan and considered 'invaluable' in the Global War on Terror (McElroy, 2007; Smith, 2006: 239-40). The latest version of the Wheelbarrow robot (Mark 9, unveiled in 2010) is built by the defence technology company Northrop Grumman and now comes with wireless operation, a touch screen and joystick (Baker, 2014; Stoker, 2012).

As this benign international template for bomb disposal is 'applied' to distant global battlefields, it carries with it all the attending colonial asymmetries and anthropocentric hierarchies that shaped the Wheelbarrow robot's birth and deployment in NI. Local infrastructures and populations in places like Iraq, Afghanistan and Pakistan are rendered disposable; collateral damage is willingly justified in order to protect occupying forces; and local populations are represented as grateful for 'life saving' devices like the Wheelbarrow robot. Indeed, the 'blow-in-place' decisions frequently made in Iraq 
and Afghanistan intensified the manner in which civilian populations, infrastructures and landscapes were made expendable in the fight against IEDs (Baker, 2014; Roderick, 2010: 248-49).

In the years since the Wheelbarrow robot's birth and deployment, the production of disposable local life-worlds has been accompanied by powerful cultural articulations of the heroic EOD robot operator whose superior human skills of intuition, judgement and decision making cannot be automated by the machine. These popular accounts romanticize the bravery of ATOs in isolation from the robots they work with and the landscapes and life-worlds they destroy - a dramatic figuration epitomized by the 'long walk' that the ATO must make to diffuse a bomb by hand. In The Hurt Locker (2008), for example, EOD robots are dispensed with altogether in favour of tense 'man vs. bomb' set pieces. In one of the film's most famous scenes, the protagonist Lt. James approaches the car bomb himself, and then takes off the heavy bomb disposal suit: 'If I'm gonna die, I'm gonna die comfortable.' Particularly interesting in relation to this film were the howls of derision from actual ATOs who found the lack of Wheelbarrow robots in the scenario laughable (Wingrove, 2010). Similarly, in his bomb disposal memoir Red One (2010: 21-30), Kevin Iveson describes the ATOs working in Iraq as 'Bomb Gods' in the style James Bond or Action man whose skills are always superior to the machines they operate (see also MacDonald, 1977: 84-85). Echoing the frustrations of his 321EOD predecessors in $\mathrm{NI}$, Iveson is constantly frustrated that the Wheelbarrow robots break down and fail. He laments that even the most technologically sophisticated versions of the robot cannot navigate the rural terrain of Iraq or access the tricky places that insurgents place IEDs, and he gets extremely angry when inefficient military bureaucracy is unable to replace the robot's faulty or worn-out parts (Iveson, 2010: 51; 83; 109). Rather than celebrating the Wheelbarrow robot as a 'game changing' piece of military technology, these popular accounts disparage the machine - or dispense with it altogether - as they super-charge the lone heroism of the ATO with his exceptional skill and bravery. 


\section{Wallowing in the Dirt:}

My dirty history of the Wheelbarrow robot ends with the cleaned-up object currently displayed in the Troubles and Beyond gallery - the object that initially sparked my unease and curiosity. What keeps me coming back is the radical contingency of this machine as an object. Like all curated objects, it signifies all over the place: its 'thing-ness' is unruly, excessive and troubling in ways that resist all the museological efforts to stabilize it. Claire, who saw the robot in 2018 for the first time since she had witnessed it as a child in the early 1970s, was brought up short by its 'real'-ness:

When I went to the Ulster Museum exhibit, I looked at the robot and said, 'Oh! It's you! What are you doing here?' It looked a little bit uglier than I remember. I remember him differently, brighter green, but that's because the sun was shining. It was the closest I had ever been to it. I did touch it... I had to. I was quite emotional at the time (personal interview, 2019).

Claire's surprise at encountering the Wheelbarrow robot after all these years speaks to the object's persistence, its implacability, and its stubbornness at surviving over four decades. For me, her reaction also speaks to the 'restlessness' of museum objects more generally - things that are always in the process of 'sliding out of joint from their expected object positions and creating, in so doing, a divergence between what things actually are and the kind of objects they are supposed to be' (Rubio, 2016: 62). With the Wheelbarrow robot, this divergence is palpable: the curated object wilfully activates more pleasurable and redemptive responses to war, but its cold steel, rubber tracks and retro controls constantly 'slide out of joint' with the governing museological narrative of the Troubles. So, is this object compliant or turbulent? Dormant or kinetic? Docile or troublesome? The answer, of course, is that it all of these things, all at once. It is precisely the restlessness of the 
Wheelbarrow robot that makes it fertile ground for thinking otherwise about the role that machines play in our stories of war.

I wanted to trace the radical contingency of this machine back through time to see how it signified during its birth and deployment in NI. What I discovered was that the British Army's 'curated' story of the Wheelbarrow robot was constantly punctured by the machine's stubborn agency, its failure to behave in human ways, and the unruly manner in which local populations reacted to its deployment. For me, the multiple trajectories, surprising counter-forces and weird instabilities that I uncovered in this dirty history of the Wheelbarrow robot were much more interesting than the easy story of a technological 'game changer' in British counter-insurgency. My intention in re-imagining war through the dirty history of one of its machines is not just to highlight the radical contingency of military technologies, or to foreground the variegated agencies that co-ordinate during episodes of 'life-saving' bomb disposal. That, on its own, is insufficient because it does not honour the critical ethos of martial empiricism. Rather, the political potential of a dirty history can only be realised if it connects the 'obvious' logics of war (e.g. civilian / combatant; battlefield / home-front) to the global circulations of colonial occupation and the manner in which those forces are experienced in everyday, intimate registers.

To show how the radical contingency of this machine extends from its birth to the present day, I want to conclude this dirty history with a mash-up. Shortly after the new Troubles and Beyond gallery was opened, Seamus visited the museum with his art class from the Northwest Regional College in Derry/Londonderry. Rather than interpret the robot in conjunction with the carefully assembled objects beside it, he associated it instead with the studded leather outfit donated by the Belfast punk band The Outkasts which is displayed on the other side of the wall (personal interview, 2019). Fig. 4 is Seamus's drawing of a 'punk' Wheelbarrow robot with a mohawk and anarchy sign, drinking a can of Harp lager and raising its middle finger. More than any heavily worked counter- 
reading or carefully exposed dirty history, this drawing exemplifies the material power of the robot a determined 'fuck you' not just to the British Army's reductive mythology and the curators' articulation of redemption, but also to my own efforts at critical historiography. [Insert Fig. 4 here]

\section{Interviews:}

Claire (2019) Personal Interview by telephone from Derry / Londonderry, $15^{\text {th }}$ April (name has been changed).

Logan, K. (2019) Personal Interview with K. Logan, principle curator of the Troubles and Beyond exhibition, Ulster Museum, $19^{\text {th }}$ March.

Niall (2019) Personal Interview, Belfast, $30^{\text {th }}$ April (name has been changed).

Seamus (2019) Personal Interview by email, $14^{\text {th }}$ April.

\section{References:}

Amar, P. (2013) The Security Archipelago: human-security states, sexuality politics, and the end of Neoliberalism. Durham, N.C.: Duke University Press.

Army Information Services (1992) '21 Years of Bomb Disposal in Northern Ireland', Press Release, $7^{\text {th }}$ November. Lisburn: Army Information Services Headquarters in Northern Ireland.

Baker, B. (2014) 'Bomb Disposal Robots - evolution and revolution', Army Technology, $12^{\text {th }}$ March, available at https://www.army-technology.com/features/featurebomb-disposal-robotsevolution-and-revolution/ (accessed 01/08/18)

Barad, K. (2007) Meeting the Universe Halfway: Quantum Physics and the Entanglement of Matter and Meaning. Durham, N.C.: Duke University Press.

Benest, D. (2006) 'Aden to Northern Ireland, 1966-76' Ch. 5 in H. Strachan, ed. Big Wars and Small Wars: The British Army and the Lessons of War in the $20^{\text {th }}$ Century. London: Routledge.

Bousquet, A; Grove, J.V. \& Shah, N. (2019) 'Becoming War: Towards a Martial Empiricism', Security Dialogue, forthcoming. 
BBC (2012) The Bomb Squad Men: The Long Walk. BBC Northern Ireland and Tern Television Productions, Dir. Brendan J. Byrne, available at https://www.youtube.com/watch?v=y$\mathrm{jL3drCH} 8$ (accessed 25/07/18).

Bigo, Didier \& Guittet, Emmanuel-Pierre (2011) 'Northern Ireland as metaphor: Exception, suspicion and radicalization in the 'war on terror', Security Dialogue, 42(6): 483-498

Bradley, A. (2019) 'Deadly force: Contract, killing, sacrifice', Security Dialogue, 50(4): 331-343.

Callaghan, K. (1993) A Price on my Head (with Terry Gorry). Wigan: Owl Books.

Davis, O. (2019) 'Theorizing the advent of weaponized drones as techniques of domestic military policing', Security Dialogue, 50(4): 344-360.

de la Bellacasa, M.P. (2010) 'Matters of Care in Technoscience: Assembling Neglected Things', Social Studies of Science, 41(1): 85-106.

Dixon, P. (2009) '"Hearts and Minds?" British Counter-Insurgency Strategy in Northern Ireland', Journal of Strategic Studies, 32(3): 445-474.

Discovery Channel (2014) Bomb Disposal Robot History, available at https://www.youtube.com/watch?v=cswKJ8rSylk (accessed 02/08/18).

Douglas, M. (1966/2002) Purity and Danger: An Analysis of Concepts of Pollution and Taboo. London: Routledge Classics.

Ellison, G. \& Smyth, J. (2000) The Crowned Harp: Policing Northern Ireland. London: Pluto Press.

Farrelly, J. (1976) "'Robot Willie" caused chaos', Evening Herald, $3^{\text {rd }}$ January, p. 1

Gill, P. (2017) 'Tactical innovation and the Provisional Irish Republican Army', Studies in Conflict and Terrorism, 40(7): 573-585.

Grove, J.V. (2019 - forthcoming) Savage Ecologies. Durham, NC: Duke University Press.

Gurney, P. (1993) Braver Men Walk Away: Memoirs of the World's Top Bomb Disposal Expert. New York: Harper Collins.

Haraway, D. (2016) Staying With the Trouble: Making Kin in the ChThulucene. Durham, N.C.: Duke University Press. 
The Hurt Locker (2008) motion picture, Voltage Pictures, USA. Directed by Kathryn Bigelow.

Irish Independent (1973a) 'Soldier dies in land mine explosion', Irish Independent, $28^{\text {th }}$ March, p. 24.

Irish Independent (1973b) 'Wilson killing "not IRA"' Irish Independent, 16 ${ }^{\text {th }}$ June, p. 24.

Keane, M. (1974) 'The most dangerous job in the North', Irish Press, $8^{\text {th }}$ April, p. 9.

Kennedy-Pipe, C. \& McInnes, C. (1997) ‘The British Army in Northern Ireland 1969-1972: From

policing to counter-terror', Journal of Strategic Studies, 20(2): 1-24.

Khalili, L. (2013) Time in the Shadows: Confinement and Counterinsurgencies. Redwood City: Stanford University Press.

Lisle, D. (2018) 'Failing Worse? Science, Security and the Birth of a Border Technology', EJIR, available at http://journals.sagepub.com/doi/10.1177/1354066117738854

Lisle, D. (2016) Holidays in the Danger Zone: Entanglements of War and Tourism (Minneapolis: University of Minnesota Press).

Machold, R. (2018) 'Reconsidering the Laboratory Thesis: Palestine/Israel and the geopolitics of representation', Political Geography, 65: 88-97.

McDonald, P.G. (1977) Stopping the Clock: Bomb Disposal in the World of Terrorism. London: Robert Hale.

McElroy, D. (2007) 'Armed robots go to war in Iraq' The Telegraph, $5^{\text {th }}$ August, available at https://www.telegraph.co.uk/news/worldnews/1559521/Armed-robots-to-go-to-war-in-

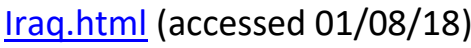

McGovern, M. (2015) 'State Violence and the Colonial Roots of Collusion in Northern Ireland', Race \& Class, 57(2): 3-23.

Meredith, F. (2018) 'New Troubles exhibition is a brave move by Ulster Museum after previous insipid effort', Belfast Telegraph, $6^{\text {th }}$ April, available at https://www.belfasttelegraph.co.uk/opinion/columnists/fionola-meredith/fionola-meredithnew-troubles-exhibition-is-a-brave-move-by-ulster-museum-after-previous-insipid-effort36778527.html (accessed 02/04/19). 
O'Connor, K. (1978) 'Arms expertise learned in North sold to Saudi Arabia', Irish Times, $27^{\text {th }}$ April, p. 10.

Our Northern Staff (1974a) 'Antrim man killed by bomb in lorry', Irish Times, $5^{\text {th }}$ August, pp. 1, 8.

Our Northern Staff (1974b) 'Explosion outside Craig's Home: Wife, 2 sons escape unhurt', Irish Times, $6^{\text {th }}$ May, p. 1

Patrick, D. (1981) Fetch Felix: The Fight Against the Ulster Bombers, 1976-1977. London: Hamish Hamilton.

Plummer, R.C. (1976) 'The right weapons for the job’ The Times, $5^{\text {th }}$ August, p. 11.

Povinelli, E.A. (2014) 'Geonologies of the Otherwise' Society for Cultural Anthropology, $13^{\text {th }}$ Janyary, available at https://culanth.org/fieldsights/geontologies-of-the-otherwise (accessed 24/04/19)

Povinelli, E.A. (2012) 'The Will to be Otherwise / the Effort of Endurance', South Atlantic Quarterly, 111(3): 453-475.

Roderick, Ian (2010) 'Considering the fetish value of EOD robots: How robots save lives and sell war' International Journal of Cultural Studies, 13(3): 235-53.

Rubio, F.S. (2016) 'On the discrepancy between objects and things: an ecological approach', Journal of Material Culture, 21(1): 59-86.

Ryder, C. (2017) 'The Freedom of Belfast would be fitting tribute to courage of 321EOD', Belfast Telegraph, $8^{\text {th }}$ February, available at https://www.belfasttelegraph.co.uk/opinion/newsanalysis/the-freedom-of-belfast-would-be-fitting-tribute-to-courage-of-321-eod$\underline{35431877 . h t m l}$ (accessed 17/06/18)

Ryder, C. (2006) A Special Kind of Courage: 321 EOD Squadron - Battling the Bombers. London: Methuen.

Salter, M. ed. (2016) Making Things International 2: Catalysts and Reactions. Minnesota: University of Minnesota Press. 
Salter, M. ed. (2015) Making Things International 1: Circuits and Motion. Minnesota: University of Minnesota Press.

Shah, N. (2017) 'Death in the Details: Finding Dead Bodies at the Canadian War Museum', Organization, 24(4): 549-569.

Smith, S. (2006) 3-2-1 Bomb Gone: Fighting Terrorist Bombers in Northern Ireland. Stroud: Sutton Publishing.

Stanhope, H. (1976) 'Exhibition tribute to Ulster Forces', The Times, $13^{\text {th }}$ July, p. 2.

Stanhope, H. (1973) 'The IRA's new fashions in terrorism', The Times, 24 $4^{\text {th }}$ May, Issue 58790, p. 18.

Stoker, L. (2012) 'Armed, aware and dangerous: the top five military robots', Army Technology, $26^{\text {th }}$ February, available at https://www.army-technology.com/features/featurearmed-awareand-dangerous-the-top-five-military-robots/ (accessed 01/08/18).

Strachan, H. (2008) 'British Counter Insurgency from Malaya to Iraq', The RUSI Journal, 152(6): 8-11, available at https://www.tandfonline.com/doi/full/10.1080/03071840701863018?casa token=a906ZfP pO6cAAAAA:2A8IYXnm6-B0q8wMoQPnkc6-Prd2uOOpB3BUi0oyiU5L-pD1GgaDcBcKbQuhio NYDQ5jKBdYtM (accessed 22/04/19)

Styles, G., Lt. Col. (1975) Bombs Have no Pity: My War Against Terrorism (as told to Bob Perrin). London: William Luscombe.

Suchman, L.E. (2007) Human-Machine Reconfigurations: Plans and Situated Actions, $2^{\text {nd }}$ ed. Durham, N.C.: Duke University Press.

Ulster Herald (1974a) 'Army blow-up 'suspect car' in John Street', Ulster Herald, 16 ${ }^{\text {th }}$ March, p. 4. Ulster Herald (1974b) Photo Essay of Goliath robot, Ulster Herald, $16^{\text {th }}$ February, p.4.

Walker, C. (1977) 'Prime Minister in 5-hour surprise visit to Ulster', The Times, $22^{\text {nd }}$ December, p. 1. Wharton, P. (2009) First Light: Bomb Disposal During the Ulster Campaign, How Sacrifice Went Unrecognized. Gloucester: Brisance Books / The Choir Press. 
Wingrove, J. (2010) 'For Soldiers, Hurt Locker sets off explosions of laughter', Globe and Mail, $5^{\text {th }}$

March, available at https://www.theglobeandmail.com/news/world/for-soldiers-hurt-

locker-sets-off-explosions-of-laughter/article1209896/ (accessed 23/07/18)

\footnotetext{
${ }^{1}$ Alan Feldman (1997) offers a helpful account of how both lethal and non-lethal technologies of watching were implicated in the wider frames of British military occupation and sectarian violence that ordered the space of NI: 'The weapon in Belfast is a perceptual instrument that organizes urban prospects and frames a historical landscape before itself' (Feldman, 1997:37). While Feldman's work on visual prostheses in NI is important, I find his account of visual technologies (e.g. cameras, gun sights, surveillance networks, windows) too human-centred, which means that agency is primarily afforded to human users and targets.

${ }^{2}$ The expansion of the Wheelbarrow robot across the world is matched by its expansion into regular policing operations and civil defence activities as exemplified in the 2016 Dallas sniper incident (Bradley, 2019; Davis, 2019). For example, police forces like the London Met and the Police Service of Northern Ireland (PSNI) continue to use robots when disarming suspect devices, and they are increasingly used in search and rescue operations (Stoker, 2012).
} 